\title{
Kajian Teologis dan Yuridis Sistem Pendidikan menurut Struktur Teks Kejadian 1:1-31
}

\author{
Theological and Judicial Study of the Educational System based on \\ Genesis 1:1-31 Structure
}

\author{
Sensius Amon Karlau \\ STT Arastamar Wamena \\ Sensiuskarlau07@gmail.com
}

\begin{tabular}{|c|c|}
\hline Article Info & Abstract \\
\hline $\begin{array}{l}\text { Submitted: } \\
\text { August } 15,2020 \\
\text { Review Start: } \\
\text { August } 28,2020 \\
\text { Accepted: } \\
\text { Sept } 2,2020\end{array}$ & $\begin{array}{l}\text { The implementation of education which refers to the juridical foundation set } \\
\text { by the government has an impact on the sustainability of theological and } \\
\text { Christian colleges in their communitarians because of the consideration of } \\
\text { theological studies according to their scientific learning outcomes. the } \\
\text { fundamental problem to be researched is how the creation story at the } \\
\text { beginning of the bible provides a perspective on the educational system } \\
\text { which is understood as a theological study. This study aims to enrich the }\end{array}$ \\
\hline $\begin{array}{l}\text { Keywords: } \\
\text { theological, } \\
\text { juridical, } \\
\text { education system, } \\
\text { Genesis, } \\
\text { Christian education. }\end{array}$ & 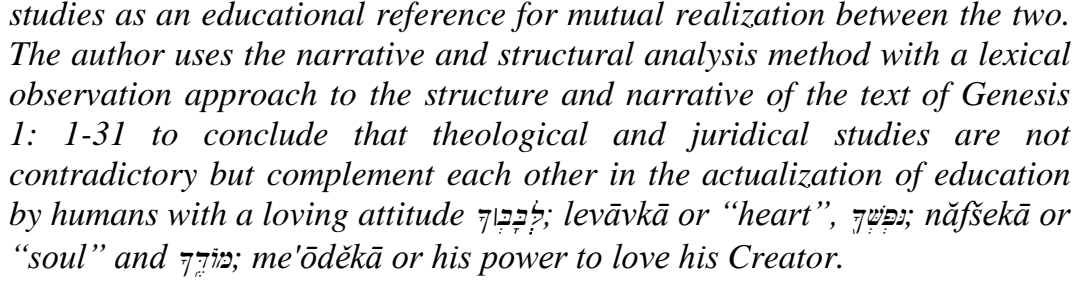 \\
\hline
\end{tabular}

[Pelaksanaan pendidikan yang merujuk pada landasan yuridis yang ditetapkan oleh pemerintah berdampak pada keberlangsungan perguruan tinggi teologi dan agama Kristen dalam komunitariannya karena pertimbangan kajian teologis sesuai learning outcome keilmuannya. Persoalan mendasar untuk diteliti yaitu bagaimana kisah penciptaan pada awal Kitab Suci memberikan perspektif mengenai sistem pendidikan yang dipahami sebagai kajian teologis. Penelitian ini bertujuan sebagai upaya memperkaya pemahaman mengenai sistem pendidikan berdasarkan kajian teologis dan yuridis sebagai acuan edukasi bagi realisasi mutual antara keduanya. Penulis menggunakan metode analisis narasi dan struktural dengan pendekatan observasi leksikal terhadap struktur dan narasi teks Kejadian 1:1-31 untuk menyumpulkan bahwa kajian teologis dan yuridis tidak saling bertentangan melainkan saling melengkapi dalam aktualisasi

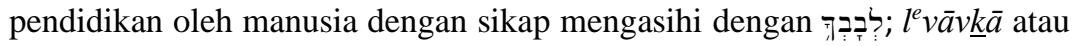

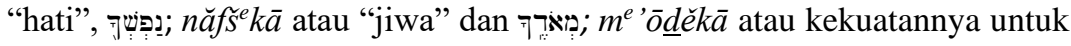
mengasihi Pencipta-Nya. 


\section{PENDAHULUAN}

$\mathrm{I}$ man Kristen menandaskan bahwa pribadi Allah selayaknya diposisikan pada tempatnya sebagai self-conscious yang mutlak, yang juga terkait dengan berbagai realitas waktu dan ruang pada segala abad karena Dia adalah pribadi yang absolud dan dapat berada secara kekal self-dependence dengan kuasa self-interpretative yang absolud. Dan, hal ini tentu termasuk di dalamnya bahwa Allah pun terlibat dengan aspek pendidikan. Pendidikan merupakan sebuah investasi penting bagi keberlangsungan peradaban dan kebudayaan manusia. Benarlah pernyataan Weinata Sairin dalam bukunya Himpunan Peraturan Pendidikan Tinggi ketika mengawali tulisannya menyatakan "dunia yang kita hidupi saat ini adalah dunia yang terus bergerak dengan segala hiruk pikuk untuk merajut peradaban baru demi kemaslahatan manusia di masa depan" . Namun realitas dan perkembangan pendidikan, khususnya pendidikan tinggi teologi dan agama Kristen, secara kualitas maupun kuantitas dianggap masih belum menunjukan finalisasi aksiologis pada berbagai harapan akan tujuan dan dampak dari pendidikan itu sendiri dalam pemahaman dan pengamatan berbagai kalangan.

Kegelisahan ini terlihat dalam komentar Uhar Suharsaputra ketika mengemukakan mengenai tantangan pendidikan pada era global yang terkait dengan internasionalisasi pendidikan tinggi dengan segala tantangan yang terus berubah. ${ }^{2}$ Ironisnya, investasi terhadap berbagai elemen penting dan cukup serius oleh sebuah bangsa yang memiliki konsen untuk pengembangan sumber daya manusianya cenderung memperoleh output yang belum memuaskan. Mardiharto mengemukakan bahwa pembangunan sumber daya manusia saat ini bahkan menjadi program prioritas pemerintah dibanding beberapa program lainnya yang mencakup pendidikan menengah hingga pendidikan tinggi, termasuk pendidikan tinggi pada bidang pendidikan agama Kristen. ${ }^{3}$ Dilema pemerintah semakin tidak menentu ketika pelaku pendidikan seringkali juga tersandra dengan warisan sejarah dari pola pendidikan yang masih mengaktualkan pola lama yang tidak relevan lagi dengan perkembangan teknologi dan ilmu pengetahuan yang semakin kompleks yang juga disertai dengan berbagai regulasi yang ditetapkan pemerintah, namun menantang untuk disikapi dan dijalani.

Salah satu unsur penting dalam upaya menggerakan kemajuan pendidikan teologi dan agama Kristen yaitu adanya rujukan akan kajian yuridis yang diharapkan selalu mempertimbangkan kultur pendidikan tinggi yang sangat kompleks karena salah satu faktornya yaitu terkait dengan ciri, bidang atau rumpun ilmu yang tentunya tidak mudah untuk dipahami secara komprehensif. Badan Standar Nasional Pendidikan (BSNP) pada kata sambutan dalam buku Himpunan Peraturan Bidang Pendidikan karya Weinata Sairin mengemukakan bahwa "kompleksitas sistem pendidikan nasional menuntut adanya aturan dasar dalam dalam bentuk Undang-Undang Dasar dan lainnya serta Peraturan Pemerintah yang lebih operasional baik dalam Peraturan Pemerintah maupun Peraturan Menteri yang dapat menjadi rujukan penting dalam pelaksanaan pendidikan ${ }^{4}$.

1 Weinata Sairin, Himpunan Peraturan Pendidikan Tinggi, 1st ed. (Bandung: PENERBIT YRAMA WIDYA, 2015), v.

${ }^{2}$ Uhar Suharsaputra, Manajemen Pendidikan Perguruan Tinggi, 1st ed. (Bandung: PT Rafika Aditama, 2015), 1-20.

3 Mardiharto, "Pembangunan Sumber Daya Manusia Melalui Bidang Pendidikan Agama Kristen," PASCA: Jurnal Teologi dan Pendidikan Agama Kristen Vol. 15, N (2019): 18.

${ }^{4}$ Weinata Sairin, Himpunan Peraturan Di Bidang Pendidikan, I. (Bandung: PENERBIT YRAMA WIDYA, 2013), v. 
Lahirnya UU No 20 tahun 2003 tentang Sistem Pendidikan Nasional menegaskan bahwa Pemerintah dan masyarakat menyadari akan pentingnya berbagai regulasi yang dapat diajdikan sebagai acuan formal dalam pelaksanaan pendidikan tinggi itu sendiri, namun perlu dipahami dengan kajian teologis dan yuridis sistem pendidikan berdasarkan analisis struktur teks Kejadian 1:1-31. Upaya ini tentunya tidak semudah membalik telapak tangan. Misalnya, dengan menetapkan standar atau acuan sebagaimana diamanatkan dalam Undang-Undang atau Peraturan Pemerintah. Salah satu pokok penting yang perlu dipahami dari berbagai sudut pandang yaitu mengenai sistem pendidikan. Karena hal mengenai adanya sistem pendidikan selalu didiskusikan dalam keberlangsungan pendidikan, termasuk pendidikan tinggi teologi dan agama Kristen. salah satu isu penting saat ini yaitu bahwa pendidikan tinggi yang diselenggarakan pada berbagai perguruan tinggi di tanah air saat ini tidak dapat lagi menganggap bahwa kurikulum hanyalah sebuah unsur pelengkap. Karena, penetapan kurikulum berdasarkan Kerangka Kualifikasi Nasional Indonesia (KKNI) yang ditetapkan Pemerintah berdasarkan Peraturan Presiden Nomor 8 Tahun 2012 menjadi acuan formal yang wajib dipahami dan diterapkan pada perguruan tinggi. ${ }^{5}$

Menariknya, pendidikan tinggi teologi dan agama Kristen diwajibkan untuk mengikuti ketentuan atau rujukan sistem pendidikan sebagaimana dimaksud. Nah, di sinilah persoalannya karena masih terdapat lembaga pendidikan tinggi teologi dan agama Kristen yang belum memahami dengan baik mengenai implementasi sistem pendidikan nasional (SISDIKNAS) secara maksimal sesuai dengan harapan Pemerintah. Lalu, bagaimana menyikapi dilema ini? Tentunya salah satu alasan pendidikan teologi teologi dan agama Kristen yang cukup klasik adalah bagaimana mengaitkan landasan yuridis dengan ciri khas dari pendidikan keagamaan Kristen yang awalnya memiliki pola dan model kurikulum yang mengacu pada kepentingan pelayanan gerejani dan hanya sedikit memahami sistem pendidikan berdasarkan acuan yang diberikan oleh Kementerian Agama, dalam hal ini yaitu Direktur Jenderal Bimbingan Masyarakat Kristen Kementerian Agama Republik Indonesia yang diketahui hanya sebagai acuan yang masih terbatas.

Memahami kajian Yuridis saja tentunya tidak cukup bagi setiap pengelola atau pendidik pada lembaga pendidikan tinggi yang bercorak keagamaan seperti sekolah tinggi teologi atau sekolah tinggi agama Kristen. Maka, di sinilah posisi dari kajian teologis yang bertolak dari pemahaman setiap tema atau pokok yang terdapat pada Kitab Suci tentunya menjadi hal penting untuk dipikirkan. Mengutip Ibrani 4:12 dan 2Timotius 3:16, Pazmino menegaskan posisi Firman Allah sebagai teks yang otoritatif yang sebaiknya dijadikan sebagai landasan dalam praktik pendidikan oleh orang Kristen, ${ }^{6}$ namun penting disadari bahwa sisi mutual dari kajian teologis dan yuridis tentunya memberikan topangan penting dalam aktualisasi perguruan tinggi teologi dan agama Kristen yang tentunya relevan dengan perkembangan ilmu pengetahuan dan teknologi saat ini dan ke depan sesuai dengan tuntutan pemerintah, gereja dan masyarakat sebagai pengguna.

${ }^{5}$ Direktorat Jenderal Pembelajaran dan Kemahasiswaan, Buku Panduan Penyusunan Kurikulum Pendidikan Tinggi Edisi III, Edisi ke-I. (Jakarta: Direktorat Jenderal Pembelajaran dan Kemahasiswaan Kementerian Riset Teknologi dan Pendidikan Tinggi, 2018).

${ }^{6}$ Robert W. Pazmino, Fondational Issues in Christian Education; an Introduction in Evangelical Perspective, 1st ed. (Michigan: Baker Academic; a division of Baker Publishing Group Grand Rapids, Michigan, 2008), 10. 
Persoalan mendasar yang menjadi fokus penulisan ini yaitu bagaimana memahami posisi dari kajian mengenai landasan dari sistem pendidikan dan pelaksanaannya, yang mana dalam perspektif komunitarian pendidikan teologi dan agama Kristen selalu melandasi berbagai aspek pelaksanaannya dengan kajian teologis yang tentunya selalu melatari segala sistem pengelolaan dan lansadannya pada Kitab Suci. Pada tataran inilah maka kemudian terdapat aplikasi real secara baik jikalau pengelola pendidikan tinggi teologi dan agama Kristen memahami dengan baik mengenai penekanan akan sistem pendidikan sebagai salah satu penunjuk arah penting dalam pelaksanaan pendidikan teologi dan agama Kristen yang kemudian bersentuhan dengan aspek lainnya dalam pendidikan yang saling kelindan sebagai sebuah bingkai penting secara mutual dalam tataran aktualisasi pendidikan.

Memahami akan pentingnya kajian teologis sebaiknya ditegaskan sejak awal penciptaan alam semsta oleh Allah. Karena melalui kisah penciptaan, sesungguhnya termaktub berbagai hal yang kemudian memungkinkan semua realitas menjadi aktual dalam berbagai kisah selanjutnya. Memang disadari di sini, dimana terkesan bahwa kisah penciptaan kurang mendapat bagian dalam aktualisasi praktis maupun akademis sebagaimana diharapkan. Kisah penciptaan terkesan menjadi kurang menarik untuk dibahas jika dibandingkan dengan kisah mengenai penebusan. Hal inilah yang kemudian disoroti dalam Bunga Rampai Teologi Perjanjian Lama Yonky Karman dalam ulasannya mengenai Penciptaan: Horizon Sejarah Keselamatan. Karman mengemukakan bahwa puncak dari marginalisasi kisah penciptaan sesungguhnya terjadi pada abad ke-19 ketika Schleiermacher dan Harnack mengembangkan prinsip teolog yang bersifat antroposentris dengan cara tafsir eksitensialis yang mana selalu berupaya untuk mencari makna teks yang dianggap menolong dirinya. Akibat dari orientasi penafsiran antroposentris ini kemudian menjadikan pembicaraan tentang Allah sebagai pencipta tidak lagi menarik untuk dibahas dengan anggapan bahwa peristiwa penciptaan alam semesta adalah peristiwa masa lalu yang sudah tidak relevan lagi dengan kehidupan manusia kekinian. Dan, yang paling penting yaitu mengenai hal keselamatan individual, dan penekanan yang berlebihan mengenai keselamatan individual ternyata berimplikasi luas sebagaimana dikemukakan oleh Claus Westermann sebagaimana dikutip oleh Karman. ${ }^{7}$

Frasa "marjinalisasi penciptaan" sebagaimana dikemukakan Yonky Karman sesungguhnya boleh dianggap atau terkesan berlebihan oleh kalangan yang tidak berani menentukan arah teologinya. Namun fakta empiris terhadap literatur kekristenan saat ini mengaminkan realitas tersebut. Maka di sinilah yang kemudian menjadi salah satu titik tolak penting, yang oleh penulis menganggap, (barangkali) dapat meminimalisir stikma "marjinalisasi" sebagaimana dikemukakan Karman. Sebab, memang benar bahwa kisah penciptaan terkesan hanya sebatas sebuah kisah yang hanya bersentuhan dengan polemik tentang ilmu pengetahuan yang membatah atau mempersoalkan siapa sesungguhnya pencipta alam semesta atau berkaitan dengan pembahasan mengenai Allah sebagai pencipta yang telah menyelesaikan karya-Nya pada masa lampau dan cukup diketahui saja dalam upaya membangun religiusitas kekinian.

Memosisikan Kitab Suci sebagai landasan otiritatif yang absolud dan bersifat formal bagi komunitariannya yakni sekolah tinggi teologi dan agama Kristen perlu dipahami dengan baik.

7 Yonky Karman, Bunga Rampai Teologi Perjanjian Lama, ed. BPK Gunung Mulia, 8th ed. (Jakarta: BPK Gunung Mulia, 2019), 20. 
Karena dalam realitas pengelolaan pendidikan teologi dan agama Kristen selalu menjadikannya sebagai acuan dalam membangun entitas pendidikannya, maka sampailah pada pokok yang penting bahwa sesungguhnya Allah adalah Pencipta, yang di dalam semua karya-Nya dilakukan dengan pola yang tersistem secara baik. Pola ini kemudian memperlihatkan kontinuitas berbagai kisah selanjutnya dalam sejarah penyataan Allah. Pertanyaan penting namun menggelitik yang perlu dipikirkan adalah: bagaimana memperlihatkan realitas penciptaan yang di dalamnya termaktub cara bekerja Allah yang tersistem? Sebab, dalam kaitannya dengan pendidikan tentunya hal ini akan selalu menjadi pertanyaan penting? Bagaimana mengaitkan kajian teologis dengan Yuridis dalam kaitannya dengan pelaksanaan pendidikan secara umum maupun pendidikan teologi dan agama Kristen yang tentunya penting karena berkelindan dengan sisi kualitas berdasarkan learning outcome dan juga sesuai kebutuhan pengguna? Apakah dua jenis atau kelompok pelaku pendidikan, dimana yang satunya menekankan mengenai pentingnya kajian teologis berdasarkan Kitab Suci sebagai acuan otoritatif dan kemudian sedikit menutup diri dengan landasan Yuridis dapat bertemu dalam sebuah bingkai pemahaman akan sisi mutual dari kedua landasan dimaksud? Maka sampailah pada rumusan masalah yang akan menjadi rujukan penting dalam penulisan ini.

Rumusan masalah atau pertanyaan dalam penelitian ini yaitu bagaimana memahami prinsip pendidikan yang terkandung dalam narasi awal penciptaan sebagaimana terdapat pada Kejadian 1:1-31, karena terdapat pandangan yang terkesan menganggap bahwa kajian teologis hanyalah pelengkap dalam pelaksanaan pendidikan teologi Kristen. Dan, menganggap juga bahwa kajian yang merujuk pada landasan Yuridis-lah yang terutama dalam aktualisasi pendidikan formal lainnya. Penelitian ini hendak mendeskripsikan bahwa kajian atau landasan Yuridis dan teologis dapat berkelindan satu dengan yang lain, serta memiliki sisi mutual (mutually exclusive) dalam tataran pelaksanaan pendidikan teologi Kristen sebagai aktualisasi Kitab Suci dalam perspektif "landasan" yang bersifat otoritatif bagi keberlangsungan pendidikan teologi Kristen yang bermutu dalam realitas yang terus mengalami perubahan.

\section{METODE}

Penulis menggunakan metode analisis narasi dan struktural dengan pendekatan observasi leksikal. ${ }^{8}$ Teknik pengumpulan data yang digunakan yaitu library research terhadap beberapa literatur yang relevan dengan pokok yang dibahas kemudian observasi leksikal terhadap setiap frasa dan klausa pada teks dengan maksud mengungkap makna asli teks Kejadian 1:1-31 sebagaimana dinarasikan oleh sang narator. Adapun upaya ini dilakukan untuk 'menarik keluar' berbagai makna dan kandungan penting mengenai tahapan penciptaan alam semesta oleh Allah yang di dalamnya memiliki kesan penting yang terkait dengan sistem pendidikan. Untuk menghindari pemahaman subjektivisme terhadap struktur dari teks dimaksud, maka langkah yang dilakukan penulis yaitu, tetap memosisikan diri secara objektif melalui pemberian makna kata tanpa memasukan latar teologis guna 'menarik keluar' makna yang lahir dari setiap kata tanpa melepas konteks dan alur kisah sebagaimana dibangun oleh narator.

${ }^{8}$ Grant R. Osborne, The Hermeneutical Spiral: A Comprehensive Introduction to Biblical Interpretation, Tjr. Spiral Hermeneutika: Pengantar Komprehensif Bagi Penafsiran Alkitab, 1st ed. (Surabaya: Momentum, 2012), 255. 


\section{PEMBAHASAN}

Pada bagian ini penulis hendak mendeskripsikan mengenai analisa singkat struktur teks dalam perspektif sistem pendidikan, landasan teologis mengenai sistem pendidikan, observasi

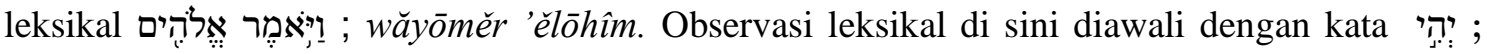

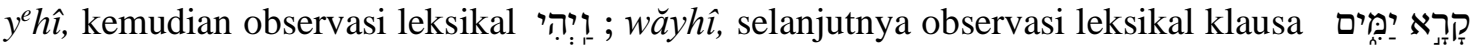

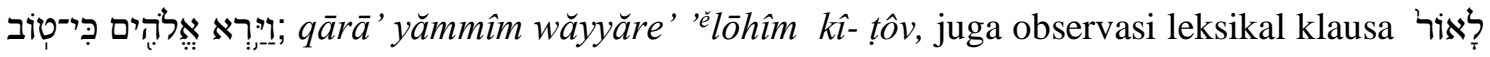

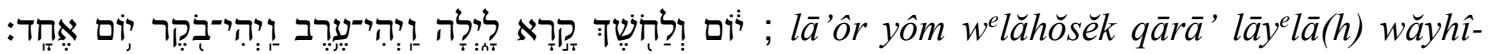

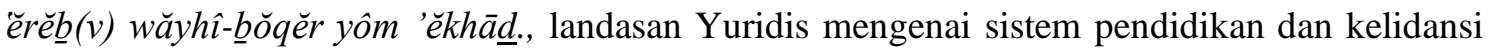
-keterkaitan hubungan timbal balik yang sangat erat dan positif serta saling mengisi antara landasan teologis dan Yuridis.

\section{Analisa Singkat Struktur Teks Dalam Perspektif Sistem Pendidikan}

Kitab Kejadian pasal 1:1-31 merupakan bagian awal dari semua kisah yang terdapat dalam teks Alkitab, baik PL maupun PB. Diawali dengan kisah tentang peristiwa penciptaan dari hari pertama hingga hari ke enam dan dikuduskan pada hari ketujuh, Tuhan Allah hendak membangun dan mengarahkan alur pemikiran bagi penikmat kisah-Nya bahwa Dialah awal dari semua hal dan kisah sejarah dunia serta alam semesta. Menarik karena kisah Kitab Kejadian dimulai dengan kisah penciptaan yang terstruktur. Ayat-ayat pembuka pada teks Kitab Suci ini menegaskan eksistensi dan pribadi Allah sebagai pelaku utama, dan juga karya penciptaan sebagai hasil karya-Nya. Selain itu kisah pembuka itu juga menceriterakan bahwa sebelum tindakan kreatif Allah yang terus terjadi secara progresif, terdapat pola susunan atau struktur yang sangat sistematis. Hal ini digambarkan Pauline A. Viviano dalam tulisannya pada Tafsir Alkitab Perjanjian Lama. ${ }^{9}$ Di sini, penulis sedikit memodifikasi susunan atau tahapan yang dilakukan Viviano untuk mempertegas posisi evaluasi terakhir yang bersifat menyeluruh yang bermakna penting dalam semua tahapan kisah dan mengarah pada lokus penting mengenai sebuah sistem pendidikan yang berimplikasi pada konkritsitasnya sebuah struktur teks yang akan mempertegas prinsip evaluasi akhir dalam semua kaya agung Allah mengenai penciptaan.
1. Pemberitahuan
: "Berfirmanlah Allah..."
2. Perintah
: "Jadilah..."
3. Laporan
: "Maka terjadilah..."
4. Evaluasi
: Allah melihat bahwa semuanya itu baik..."
5. Uvaluasi Akhir
: Maka Allah melihat segala yang dijadikan-Nya itu, sungguh amat baik

6. Bingkai waktu: “Jadilah petang..." jadilah pagi..."

Kesan penting pernyataan Viviano di sini memperlihatkan alur atau struktur yang sangat jelas dan menarik untuk mengambarakan tahapan demi tahapan pada setiap karya penciptaan yang diprakarsai oleh Allah sendiri. Bahwa setiap hasil karya Allah selalu memiliki tendensi penting yang diawali dengan sebuah rencana yang kemudian megacu pada sasaran utama untuk memperlihatkan keterukuran dan ketercapaian sebuah "karya ciptaan" yang juga selalu diakhiri dengan bentuk evaluasi atau penilaian. Hal ini tentunya penting mengingat semua hasil karya

${ }^{9}$ Pauline A. Viviano, Tafsir Alkitab Perjanjian Lama, ed. Diane Bergent dan Robert J. Karris, 13th ed. (Yogyakarta, 2002), 34. 
yang dihasilkan akan "dikuasai" oleh ciptaan yang paling terakhir namun memiliki potensi terbaik yaitu manusia.

\section{Kajian Teologis Mengenai Sistem Pendidikan}

Proposisi kajian teologis dan kajian alkitabiah dapat dibahas secara terpisah walaupun tentunya saling terkait sebagaimana dilakukan oleh Pazmino. ${ }^{10}$ Namun beberapa literatur lain menganggapnya sebagai hal yang tidak perlu dibedakan karena memiliki esensi yang sama karena merujuk pada teks Kitab Suci. Hal ini misalnya terlihat dalam tulisan Groom' ${ }^{11}$ atau Sidjabad yang dalam tulisannya menggunakan terminologi landasan teologis namun mengutip beberapa teks Kitab Suci dalam pembahasannya' ${ }^{12}$ yang oleh Pazmino dibahas secara terpisah dengan mengawalinya dengan landasan teologis. Namun pada sisi yang lain dan tentunya menarik adalah bahwa sepakatnya para teoretikus pendidikan agama Kristen mengenai pentingnya sebuah tatanan atau sistem pendidikan sebagai faktor penting bagi eksistensi manusia dan peradabannya yang terlibat aktif sebagai pengelola lembaga pendidikan, baik pendidikan informal, pendidikan non formal dan lebih lagi bagi lembaga pendidikan formal, termasuk perguruan tinggi teologi dan agama Kristen yang tentunya berbasis keagamaan.

Pemikiran yang penting untuk didiskusikan adalah mengenai titik berangkat kajian teologis dalam pembahasan mengenai pendidikan agama Kristen. Lebih tegas dari Amos Neolaka yang melandasi pemikirannya bahwa pendidikan sudah termaktub dalam kisah penciptaan pleh Allah dalam Kitab Kejadian, ${ }^{13}$ Cornelius van Til pun melontarkan sebuah kalimat penting bahwa pendidikan Kristen sesungguhnya berakar pada kisah penciptaan alam semesta. ${ }^{14}$ Sejalan dengan van Til, Richard J. Edlin menyatakan bahwa landasan mengenai pendidikan dan hal lainnya dalam pendidikan Kristen harus kuat dan aman menurut Alkitab, dan disegarkan melalui pengembangan profesional secara teratur bila struktur yang dibangun di atasnya ingin bertahan dan berkembang. ${ }^{15}$ Di sini, penulis memahami bahwa baik Neolaka, van Till dan Edlin bersama-sama memberikan penekanan pada titik berangkat mengenai prinsip pendidikan, khususnya pendidikan Kristen yang tentunya bersifat antithesis dengan pemikiran pendidikan yang bukan berkaitan dengan teistik Kristen. Maka penulis menganggap bahwa upaya pemberian makna pada beberapa ayat Alkitab sebaiknya dikaji atau dianalisa secara baik agar dapat menjadi landasan penting dalam membangun kerangka pemikiran yang konstruktif dan konprehensif menegnai sistem pendidikan teologi Kristen saat ini maupun ke depan.

Beberapa sitiran penting yang dikemukakan sebelumnya menegaskan betapa pentingnya memosisikan kajian teologis sebagai sebuah rujukan penting dalam koprehensifitasnya sistem pendidikan yang relevan bagi keberlangsungan lembaga pendidikan teologi dan agama Kristen

10 Pazmino, Fondational Issues in Christian Education; an Introduction in Evangelical Perspective.

11 Thomas H. Groome, Christian Religious Education; Pendidikan Agama Kristen, 6th ed. (Jakarta: BPK Gunung Mulia, 2017).

12 B.S. Sidjabad, Mengajar Secara Profesional: Mewujudkan Visi Guru Profesional, 4th ed. (Bandung: Yayasan Kalam Hidup, 2011).

${ }^{13}$ Amos Neolaka, Isu-Isu Kritis Pendidikan; Utama Dan Tetap Penting Namun Terabaikan, 1st ed. (Jakarta: PRENADAMEDIA GROUP, 2019), 1-2.

${ }^{14}$ Louis Berkhof \& Cornelius van Til, Foundations of Christian Education. Trj. Dasar Pendidikan Kristen, kelima. (Surabaya: Momentum, 2013), 69.

${ }^{15}$ Richard J. Edlin, Hakikat Pendidikan Kristen, 1st ed. (Jakarta: BPK Gunung Mulia Bekerja Sama Dengan Badan Pendidikan Kristen Penabur, 2015), 233. 
sekarang ini. Dalam tekanannya pada tulisan mengenai antithesis dalam pendidikan, Cornelius van Til beberapa kali menekankan pentingnya memahami dan menempatkan Allah pada segala kegiatan pendidikan Kristen yang memiliki kekhasan tersendiri. ${ }^{16}$ Maka kajian teologis sesungguhnya merupakan pengejawantahan Allah sebagai subyek utamanya dan karya-Nya, yang perlu dipahami dengan baik sejak sebagaimana delam awal kisah penciptaan pada Kitab Suci sebagai kisah penting yang relevan dan aktual dengan segala perkembangan pendidikan Kristen yang perlu digelorakan terus-menerus. Berbagai upaya marginalisasi kisah penciptaan sesungguhnya perlu disoroti berdasarkan komprehensifitas pemahaman yang bertanggungjawab berdasarkasn Kitab Suci bahwa kisah penciptaan sesungguhnya adalah kisah penting yang bersentuhan dengan berbagai aspek kehidupan manusia dan alam semesta, yang tentunya juga termasuk di dalamnya mengenai aspek pendidikan dimana Allah dalam self-dependence-Nya terlibat secara aktif.

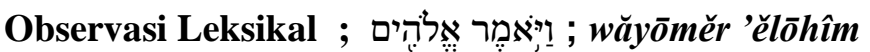

Narator mengemukakan pada Kejadian pasal 1, ayat 1 sampai 31 pada Kitab Kejadian yang diawali dengan frasa "berfirmanlah Allah". Frasa ini disebutkan 9 kali dan kata Firman-Nya sebanyak 1 kali sehingga jika dijumlahkan maka terdapat 10 kali kata "Allah berfirman". Frasa

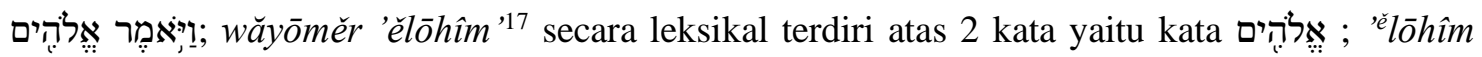
yakni Allah sebagai subyek atau pelaku utama dan kata wăyōměr. Kata wăyōměr berasal dari kata dasar אמר ; āmăr yang digunakan 5280 kali. Kata āmăr di sini menggunakan kata penghubung wă yang berarti “dan”. Kata אמר ; sederhana yaitu "kata", "mengatakan" dan "berfirman". Namun secara mendalam kata אמר ; àmăr digunakan dengan beberapa pengertian yaitu a) sebagai pernyataan yang memiliki kesan sebagai sebuah proklamasi, pidato, the simle rendering of speech. b) 'in order to say' usually means as he/she said, with these words; kata yang di dalamnya mengadung perintah, umumnya digunakan sebagai sarana atau cara Dia (subyek) di sini yaitu Tuhan yang berkata atau berfirman, c) berfirman, sebutan dengan kesan "memuji sebab terkait juga dengan perjanjian atau adanya harapan", kemudian juga dapat berarti "think", berpikir atau merenung. ${ }^{18}$ NIV dan KJV menerjemahkan kata ini dengan "said" yang dapat berarti suara, mengatakan, atau

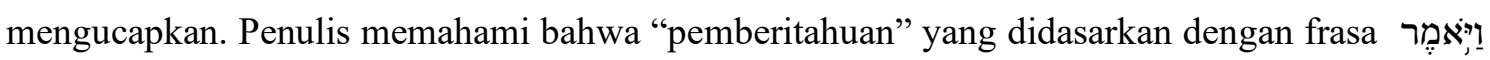

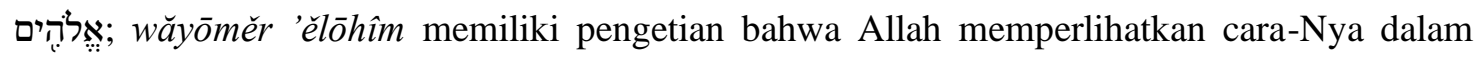
mencipta. Maka "think" sebagai ungkapan atau perenungan disini menunjuk kepada sebuah bentuk pernyataan yang bersifat proklamasi atau bentuk demonstrasi sebuah "cara" untuk mewujudnyatakan "sesuatu" yang dikehendaki atau menjadi berwujud yang ber-realitas yang juga memiliki harapan. Term "harapan" dipahami sebagai karya mencipta oleh Allah yang memiliki dampak menyenangkan pada masa sekarang dan masa depan.

${ }^{16}$ Til, Foundations of Christian Education. Trj. Dasar Pendidikan Kristen, 3-36.

17 Thom Blair, The Hebrew-English Interlinear ESV Old Testament, Biblia Hebraica Stuttgartensia English Standard Version, ed. Thom Blair, 13th ed. (Wheaton, Illinois: CROSSWAY : Wheaton, Illinois - www.Esvbible.org, 2014), 1.

${ }^{18}$ Koehler-Baumgartner, A Concise Hebrew Aramic Lexicon of the Old Testament, ed. William L. Holladay, 1st ed. (Leiden, the Nedherlands, 1971), 21. 
Penekanan penting di sini berkaitan juga dengan oknum atau subyek utama yaitu Allah sebagai pelaku utama yang mencipta dengan "kata atau Firman" yang keluar dari mulut-Nya yang penuh kuasa dan memberikan harapan akan terwujudnya sebuah karya cipta. Dan, karya cipta yang menjadi sebuah realitas tentu berfungsi untuk memproklamirkan eksistensi Allah sebagai pribadi yang berkuasa serta berdaulat bagi segenap ciptaannya. Pada frasa pertama ini, penulis memahami bahwa dalam meralisasikan segala hal, diperlukan akan pengakuan kepada Allah sebagai oknum utama yang mampu mewujudnyatakan apa yang hendak dinyatakan. Pendidikan merupakan sebuah bentuk proklamasi manusia yang satu kepada manusia lainnya mengenai segala realitas yang perlu disikapi secara baik. Karena melalui pendidikanlah, sebuah kebenaran tentang setiap realitas yang memiliki harapan akan masa depan dapat diketahui dan dipergunakan sebagaimana mestinya. Dan, hal penting yang perlu dipahami dengan baik adalah mengenai aktor penting yakni Allah.

\section{Observasi Leksikal יִינ: ; $y^{e} h \hat{\imath}$}

Selanjutnya, kata yang berikut adalah "jadilah" yang memiliki kesan perintah. Kata "jadilah" berasal dari kata Ibarani יִיִ ; $y^{e} h \hat{\imath}$ dari kata dasar $h \bar{a} y \bar{a}(h)$, et him be. ${ }^{19}$ Kata ; $y^{e} h \hat{\imath}$ dari kata dasar hāya $(h)$, et him be ini adalah kata kerja qal imperfek orang ketiga maskulin tunggal. Bentuk qal di sini yaitu menunjuk kepada sebuah penekanan tentang sebuah tindakan nyata. Secara gramatikal Imperfek dapat menyuguhkan sejumlah bentuk tindakan khas yang sering terjadi dan menunjuk kepada waktu “[sekarang ini] Dia [Allah] menjadikan." Penulis meyakini bahwa bentuk imperfek di sini yaitu imperfek injungtif, yakni menekankan sesuatu tindakan yang serius dan kuat. Ini berarti bahwa kata י্:; yeh dari kata dasar hāyā(h), et him be memiliki pengetian yang menunjuk kepada "waktu atau saat dimana Allah hendak melakukan sebuah

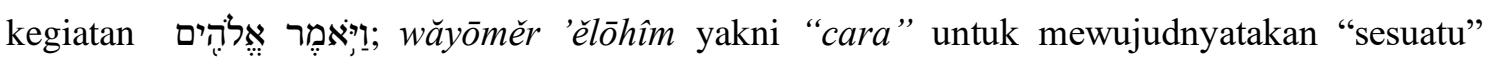
melalui kata "jadilah" yang menjadi berwujud untuk diketahui berdasarkan sebuah niat atau kehendak yang sangat serius dan tegas.

Telah dikemukakan pada frasa sebelumnya bahwa sebuah kegiatan apapun yang hendak dilakukan tidak cukup hanya pada ranah theoria belaka. Sebab, diperlukan adanya sebuah aktualisasi real mengenai apa yang hendak dinyatakan. Dan dalam upaya merealisasikan apapun juga, semuanya terjadi dalam ranah "waktu" atau kesempatan yang perlu disikapi dengan bijaksana. Bahwa Allah, di dalam merealisasikan segala rencananya, selalu terlihat rapih dan tertata dengan baik. Diawali dengan tindakan "berfirman" untuk mencipta sesuatu, kemudian narator memberi gambaran mengenai realisasi pendiptaan dengan kata "jadilah". Kata ini menandaskan juga kesan penting mengenai keseriusan Allah dalam merealisasikan segala sesuatu. Maka tentunya, upaya mengaktualkan sesuatu diperlukan tingkat keseriusan dalam "kesempatan" yang di dalamnya kemudian akan terjadi dengan serius.

\section{Observasi Leksikal}

Setelah narator mengemukakan mengenai "cara mencipta", oleh Allah, kemudian delanjutkan dengan term penting yakni mengenai keseriusan untuk merealisasikan sebuah karya cipta,

19 Blair, The Hebrew-English Interlinear ESV Old Testament, Biblia Hebraica Stuttgartensia English Standard Version, 1. 
kemudian dilanjutkan dengan sebuah deklarasi penting bahwa sesuatu yang hendak diciptakan itu telah "terjadi" dan kemudian sesuatu yang telah diciptakan itu kemudian dilaporkan.

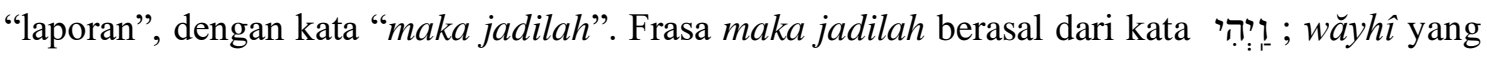

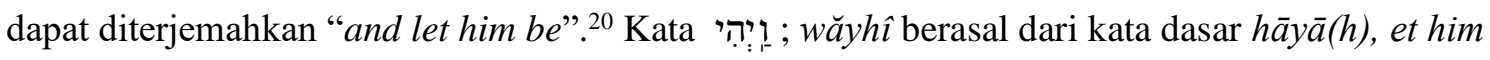
be. Kata ; $y^{e} h \hat{\imath}$ dari kata dasar $h \bar{a} y \bar{a}(h)$, et him be ini adalah kata kerja qal imperfek orang ketiga maskulin tunggal. Namun di sini pengertian atau maknanya berbeda dengan kata $h \bar{a} y \bar{a}(h)$, et him be yang memiliki pengertian "perintah" sebagaimana di atas, melainkan menunjuk kepada sebuah laporan tentang keberadaan "hasil ciptaan" yang sudah jadi atau berwujud dan terlihat sebagaimana pengertian literalnya yaitu "dan atau maka [sekarang] dia [sesuatu] menjadi ada". Di sini, kata penghubung $w a$ (TB-LAI: maka) menjadi penting karena memberikan kesan bahwa sebuah kegiatan sedang dijadikan [diciptakan].

Sampai di sini, penulis memahami bahwa narator hendak mengemukakan tentang cara kerja Allah, yang dalam peristiwa penciptaan sesungguhnya bukan hanya asal mencipta saja, melaikan melakukannya dengan sebuah tahapan dan pola kerja yang jelas dan terukur. Maka disinilah yang kemudian dipahami sebagai sebuah sistem atau cara yang bersifat sistema. Karena melalui sebuah "sistem" seseorang dapat melakukan sesuatu berdasarkan tahapan dan titik berangkatnya hingga menuju ke tujuan yang hendak dicapai.

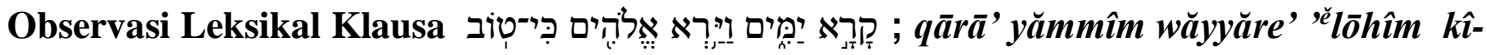 $t \hat{o} v$}

Narator memberikan informasi bahwa setelah setiap ciptaan "dilaporkan keberadaannya", וְיְְ ; wăyhî yang dapat diterjemahkan "and let him be, maka selanjutnya pada bagian ini penulis

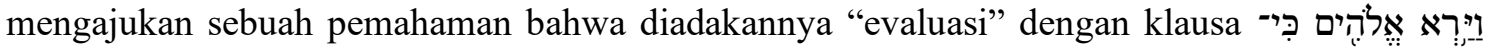

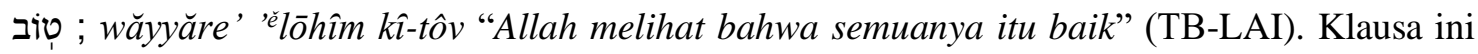
dikemukakan oleh narator sebanyak 5 kali yaitu pada ayat 10;12; 18; 21; dan 25 serta satu kali dengan ungkapan "sungguh amat baik. Klausa "Allah melihat bahwa semuanya itu baik"

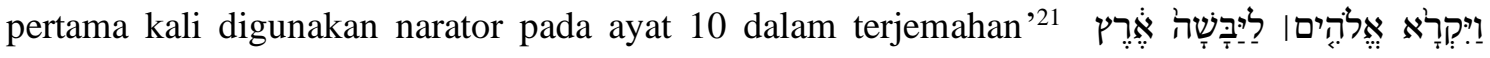

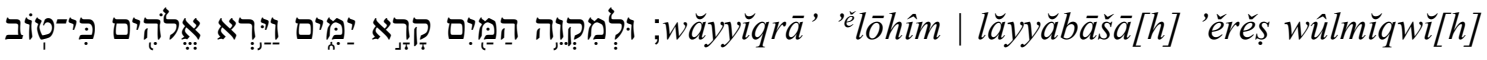

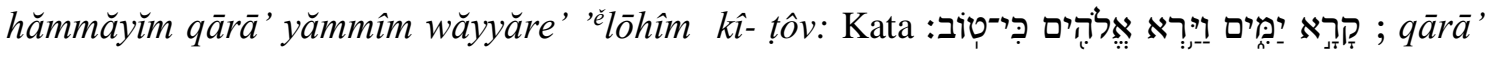
yămmîm wăyyăre' 'èlōhîm kî̀-țôv. NIV menerjemahkan kalimat ini yakni God called the dry ground "land," and the gathered waters he called "seas." And God saw that it was good. Victor P. Hamilton mengemukakan bahwa pada bagian ini (ayat 10), adalah sebuah peralihan dimana Allah telah mengakhiri semua yang diciptakan yang memiliki ruang di atas atau angkasa. Dan sekarang Allah hendak meneruskan penciptaannya yang terkait dengan benda-benda yang di bumi. ${ }^{22}$ Menarik karena pada fase penciptaan Allah mengenai benda-benda angkasa dan hendak

${ }^{20}$ Blair, The Hebrew-English Interlinear ESV Old Testament, Biblia Hebraica Stuttgartensia English Standard Version.

21 (WTT Leningrat Hebrew Old Testament Dalam BibleWorks9, LLC, 2011)

${ }^{22}$ Hamilton Victor P, The New Internastional Commentary on the Old Testament: The Book of Genesis Chapter 1-7, ed. JR R.K. Harrison \& Robert L. Hubbard, 13th ed. (Grand Rapids, Michigan, 1990), 125. 
beralih untuk benda-benda di bumi inilah maka narator menggemukakan sebuah kalimat penting bahwa semua yang dilihat Allah itu baik adanya.

Masih terkait dengan evaluasi, sebagaimana diketahui bahwa narator menggunakan kata qāāa' yămmîm wăyyăre' 'ě lōhîm kî- tôvv sebanyak empat kali yang artinya And God saw that it was good (NIV), maka narator mengakhiri kisah penciptaan dalam pasal 1 ayat 31 dengan evaluasi terakhir yang dikemukakan dan tentunya perlu dianalisa untuk dapat memosisikan fungsi evaluasi akhir yang kemudian penulis meyakini bahwa akan terdapat sebuah lema penting untuk memaknai prinsip evaluasi pada akhir sebuah karya. Secara menyeluruh, ayat 31 dideskripsikan demikian oleh. ${ }^{23}$ Bentuk kata kî̀- tôv yang terdiri atas kata depan kî dan kata tôv yang merupakan kata sifat dengan bentuk qal. Maka di sini dapatlah dipahami bahwa Allah sedang aktif untuk membuat sebuah penilaian. Ke-aktifan Allah berdasarkan inisiatif-Nya penting dipahami sebagai sebuah tindakan lanjutan terhadap apa yang sudah dilakukan atau diciptakannya. Dalam kaitannya dengan pendidikan; tentunya terkait dengan sebuah sikap atau inisiatif yang akif dan kreatif serta inovatif dari seseorang yang terlibat dalam upaya efektifitas pendidikan untuk selalu aktif dan berkontribusi dengan serius terhadap apa yang sudah dilakukannya.

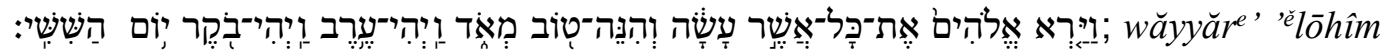

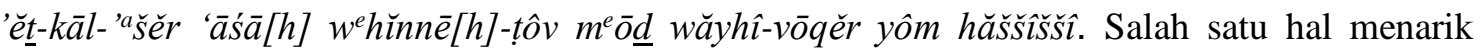

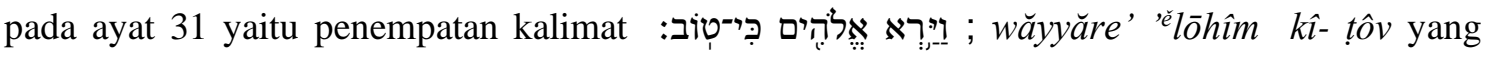
merujuk pada bentuk evaluasi rupanya bukan berada pada akhir dalam struktur bahasa yang dibangun oleh narator sebagaimana empat kali digunakan pada ayat-ayat sebelumnya. Di sini, frasa yang menunjuk pada adanya sebuah bentuk evaluasi berada pada awal kalimat

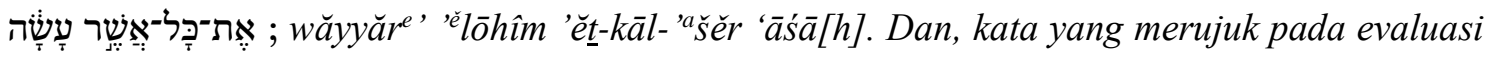

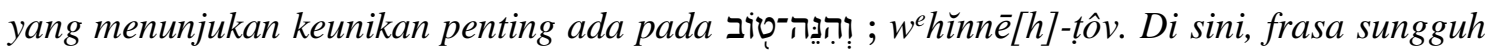
atau "sesungguhnya". Adalah kata yang juga dapat diterjemahkan "lihatlah". Namun penulis menggunakan terjemahan "sesungguhnya" karena kata yang sama digunakan juga pada Kejadian 3:22; Bilangan 23:9, 24; Ulangan 3:11 dan lainya yang tentunya memiliki konteks yang berbeda-beda. Petimbangan terjemahan "sesungguhnya" di sini, sekali lagi adalah untuk memperlihatkan finalisasi penilaian pada segala karya penciptaan, dimana diakhiri dengan penciptaan manusia pada hari ke enam. Penulis menganggap bahwa tentunya LAI pun memiliki latar pemikiran yang sama mengenai bentuk evaluasi akhir yang dilakukan Allah di sini dengan terjemahan maka Allah melihat segala yang dijadikannya itu, sungguh amat baik jadilah petang dan jadilah pagi itulah hari keenam [ayat 31] TB-LAI. Dalam frasa ini, dua kata yang penting untuk memahami "evaluasi" yaitu kata kerja "melihat" dan kata sifat "baik" yang dipertegas dengan kata "sesungguhnya".

Terkait dengan adanya sebuah sistem dalam pelaksanaan pendidikan, evaluasi merupakan salah satu hal penting yang perlu dilakukan, baik evaluasi pada tahap awal, pertengahan maupun akhir dari sebuah proses yang berskala kecil maupun besar atau menyeluruh. Khoe Yao Tung dalam tulisannya melontarkan sebuah pendapat bahwa evaluasi yang dilakukan dalam proses pendidikan merupakan "Segala upaya keseriusan peningkatan kualitas pendidikan tercermin

23 "WTT Leningrat Hebrew Old Testament Dalam BibleWorks9, LLC." 
dari keseriusan evaluasi hasil pembelajaran, mulai materi soal (validitas, realibilitas dan daya pembeda), pelaksanaan ujian, dan proses penilaian. Upaya membangun nilai-nilai kejujuran, ketekunan, ketelitian, dan kerja keras dipertaruhkan dalam pelaksanaan ujian". ${ }^{24}$ Selanjutnya Tung mengutip pernyataan Haro van Brummelen tentang prinsip-prinsip penilaian [evaluasi] sekolah Kristen yang mendasarkan iman Kristen, assessment, bukanlah judgement melainkan gift. Pernyataan Yao Tung menandaskan pentingnya sebuah proses evaluasi pada sebuah system yang dibangun dalam kaitannya dengan pendidikan.

Kembali ke teks Alkitab yang menunjuk kepada hal evaluasi yaitu "dan Allah melihat bahwa itu baik." Menarik karena setiap saat ketika sebuah karya penciptaan diadakan, Allah selalu memberikan evaluasi dengan pernyataan yang sama yakni Allah melihat semuanya itu baik." Kata melihat di sini menggunakan kata וּר ; wăyyăre' dari kata dasar ; berarti and he saw, ${ }^{25}$ dan Dia melihat. Pengertian lebih dalam dari kata $; r \bar{a} ' \bar{a}(h)$ adalah bentuk infleksi stem kata kerja qal'. Secara gramatikal, stem kata kerja qal adalah stem paling dasar dari verba. Dari qal inilah enam stem lain didapatkan. Qal diklasifikasikan sebagai stem aktif sederhana walaupun qal juga memiliki partisip pasif. ${ }^{26}$ Maka artinya di sini adalah "melihat dengan aktif (Kej. 27:1; Kel. 24:10; Maz. 40:2, menjenguk); dan memandang. Namun kata yang sama ketika berubah bentuk infleksi stem kata kerja nifal, maka artinya yaitu "dapat dilihat" (Kej. 1:9; 9:16), menampakan diri (Kej. 46:29/LAI: bertemu; Kej. 12:7; 17:1; 18:1; 26:2 dll.); accusative according- "melihat"; $P u$ "dilihat" (Ayb. 33:21); Jika bentuknya bentuk infleksi stem kata kerja hifil, maka memiliki pengertian "menunjukan, menyatakan; memperlihatkan (Yer. 24:1; 38:21; Yeh. 11:25; 40:4; Am. 7:1,4,7; 8:1; Hab. 1:3; dll memberikan arti "visi" seperti Za. 2:2, dll); bentuk berubah menjadi bentuk infleksi stem kata kerja hofal, berarti "ditunjukan" (Im. 13:49/LAI: diperiksa; U1. 4:35/LAI: diberikan melihat); kemudian bentuk infleksi stem kata kerja hitpail, memiliki pengertian "berpandang-pandangan" (kej. 42:1); menunjukan/mengadu tenaga dalam perang seperti pada 2 Raj 14:8, 11). ${ }^{27}$

Pemaparan tentang kata $r \bar{a} \bar{a}^{\prime}(h)$ dengan pengertian dan penggunaanya dalam tata bahasa Ibrani di atas adalah sebagai bentuk penyelidikan mendalam tentang makna kata itu sendiri sesuai dengan konteksnya. Meskinpun secara tata bahasa, sebuah bentuk infleksi kata kerja (misalnya bentuk qal) pada sebuah bagian tidak dapat diubah ke bentuk lain, namun sebuah spekulasi yang terukur tentunya dapat memberi makna lebih pada sebuah teks dalam peruntukannya. Maka tidaklah berlebihan jika kata $r \bar{a}{ }^{\prime} \bar{a}(h)$ di sini adalah menunjuk kepada sebuah proses "melihat, atau menjenguk yang sifatnya sekaligus memeriksa hasil pekerjaan yang sudah "terwujud" oleh Allah sendiri dengan maksud menilai kualitas atau mutu dari ciptaan tersebut. Maka disinilah penulis menegaskan tentang pentingnya sebuah evaluasi atau pemeriksaan atau penilaian tentang sebuah hasil karya.

24 Khoe Yao Tung, Terpanggil Menjadi Pendidik Kristen Yang Berhati Gembala, 1st ed. (Yogyakarta: Penerbit ANDI (Penerbit Buku dan Majalah), 2016).

25 Blair, The Hebrew-English Interlinear ESV Old Testament, Biblia Hebraica Stuttgartensia English Standard Version, 1.

26 Page H. Kelley, Biblical Hebrew: An Introductory Grammar, Second edi. (Grand Rapids, Michigan: William B. Eerdmans Publishing Company, 2018), 518.

${ }^{27}$ Reinhard Achenbach, Kamus Ibrani-Indonesia Perjanjian Lama (Jakarta: Yayasan Komunikasi Bina Kasih, 2008), 306. 
Dalam konteks pendidikan, kata "Dia yang menunjuk kepada Tuhan melihat" memiliki pengertian mendalam yaitu bahwa Tuhan sendiri memeriksa atau mengevaluasi. Mariani Harmadi dan Abednego Agung Jatmiko mengemukakan bahwa pendidikan agama Kristen selalu merujuk pada sentralitas Yesus Kristus dan Roh Kudus sebagai penyerta untuk mengalami pertumbukan iman yang berdampak pada pertumbuhan iman yang hidup dan bertanggungjawab untuk berkontribusi bagi segala perubahan sosial sehingga diperlukan tindakan evaluasi dan kajian terhadap input maupun output berdasarkan misi amanat agung 'ajarlah' dalam Matius 28:19-20. ${ }^{28}$ Kesan penting di sini yaitu bahwa setiap pelaku pendidikan perlu mengadakan proses evaluasi pada awal, pertengahan atau akhir dari sebuah proses pelaksanaan pendidikan dengan tilikan yang mendalam secara aktif sebagai bentuk pertanggungjawaban sosial terhadap sebuah kegiatan pendidikan yang dilakukan. Dan hal ini dapat dilakukan dengan baik, tidak hanya oleh seseorang melainkan juga sekelompok pelaksana proses pendidikan yang tentunya merujuk pada sebuah system baku berupa rubrik penilaian atau lainnya yang ditetapkan dengan mempertimbagkan beberapa aspek penting guna mengetahui tingkat kualitas dari keberlangsungkan pendidikan itu sendiri.

Selanjutnya, kata sifat baik di sini yang dikaitkan dengan obyeknya yaitu Allah" berasal

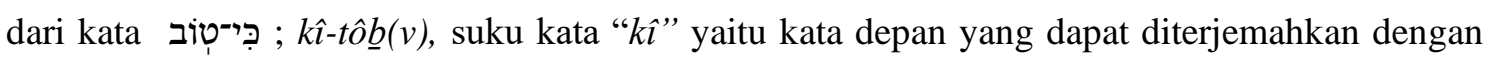
kata "karena" atau "sebab" yang menunjuk kepada kata sifat "baik atau bagus". Maka kata depan "karena" atau "sebab" memperlihatkan peroses penilaian itu sendiri yang diakhiri dengan hasil yaitu adjective "baik atau bagus". Kata yang sama dapat dilihat dalam (Ul. 6:18; Ams. 24:13, dll); (hak. 11:3, 5; 2Sam. 10: 6, 8). Menarik akan apa yang dikemukakan Amos Neolaka dalam bukunya "isu-isu kritis pendidikan, utama dan tetap penting namun terabaikan" bahwa dalam frasa "dan Allah melihat semuanya sungguh amat baik" merupakan sebuah proses atau tahapan evaluasi dalam aspek pendidikan, dan ini menunjukan bahwa pendidikan itu dimulai dan dianjurkan oleh Allah sendiri. ${ }^{29}$

Dengan demikian maka, frasa "dan Allah melihat semuanya itu baik" atau "maka Allah melihat segala yang dijadikan-Nya itu sesungguh amat baik" adalah sebagai bentuk penilaian atau evaluasi mendalam mengenai sebuah hasil karya "mencipta." Yang dapat dikaitkan dengan adanya sebuah system pendidikan yang tidak pernah atau tidak boleh berhenti dilakukan. Karena, melalui proses evaluasi mendalam yang diadakan dengan bertanggungjawab dan terukur guna menilai kualitas atau mutu sesuai dengan tujuan dari pendidikan itu sendiri. Dan pada akhirnya proses penilaian atau evaluasi itu menghasilkan hasil yang baik atau bagus.

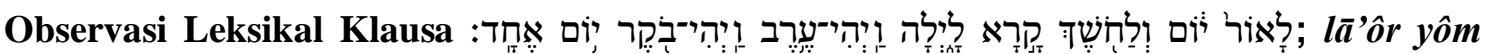

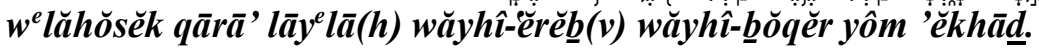

"Jadilah petang..." jadilah pagi.... Kata jadilah digunakan dua kali untuk menunjuk kepada dua bentuk waktu yaitu "petang" dan "pagi". Kata jadilah yang digunakan di sini dalam teks Ibraninya adalah kata היוְיז; wăyhî yang berasal dari kata dasar $h \bar{a} y \bar{a}(h)$ yang dapat diterjemahkan "ada; berada; menjadi; terjadi; berlangsung (Kej. 3:1; 1Sam. 25:43, dll)".

28 Mariani Harmadi \& Abednego Agung Jatmiko, "Pembelajaran Efektif Pendidikan Agama Kristen Generasi Milenial,” PASCA: Jurnal Teologi dan Pendidikan Agama Kristen Vol. 16, N (2020): 67.

\footnotetext{
${ }^{29}$ Neolaka, Isu-Isu Kritis Pendidikan; Utama Dan Tetap Penting Namun Terabaikan, 1.
} 
Terjemahan BIS dan TB-LAI sama-sama menerjemahkan kata וָיז: ; wăyhî dengan "jadilah". Maka penulis dapat memaknai kata "jadilah" di sini sebagai sebuah "kenyataan" yang berwujud dan memperlihatkan eksistensinya. Pertanyaannya adalah "apakah yang menjadi kenyataan?" maka jawabannya secara sederhana yaitu menunjuk kepada kenyataan tentang adanya "petang" dan adanya "pagi" dimana sama-sama menunjukan perbedaanya yang saat ini dapat dipahami sebagai "waktu". Tim penyusun Kamus Besar Bahasa Indonesia memberikan definisi "petang" yaitu "waktu sesudah tengah hari, kira-kira dari pukul tiga sampai matahari terbenam". ${ }^{30}$ Selanjutnya "pagi" yaitu "bagian awal dari hari atau waktu setelah matahari terbit hingga menjelang siang hari. Maka jadilah "petang" dan jadilah "pagi" adalah sebuah penegasan tentang keberadaan waktu yang terlihat dengan eksistensinya untuk membedakan waktu "petang" dan waktu "pagi".

Dengan demikian maka dapat dipahami bahwa hal pemberitahuan: "berfirmanlah Allah...", hal perintah: "jadilah...", dan hal laporan: "maka terjadilah...," hal evaluasi : "dan Allah melihat bahwa itu baik...," yaitu evaluasi awal dan pertengahan serta evaluasi akhir "maka Allah melihat segala yang dijadikan-Nya itu sungguh amat baik", serta hal mengenai bingkai waktu: "jadilah petang..." jadilah pagi... adalah bagian sentral dari hal mengenai sistem pendidikan yang perlu ditata, diatur dengan sebuah pola atau model yang mempertimbangkan semua realitas, konteks dan kultur sebuah bangsa yakni bangsa Indonesia agar menjadi semakin berkembang dalam segala persaingan sumber daya manusia secara menglobal. Sekali lagi, perlu dipertegas bahwa pelaksanaan pendidikan, juga di dalamnya pendidikan tinggi teologi dan agama Kristen perlu ditata dan dirancang sedemikian rupa dengan sistem yang baik dan terus mengupayakan berbagai langkah strategis secara bertahap dan terukur sesuai dengan cita-cita bangsa, juga tujuan tertinggi Ilahi yaitu "memanusiakan manusia seutuhnya".

\section{Kajian Terhadap Landasan Yuridis mengenai Sistem Pendidikan}

Keberlangsungan pendidikan formal tentunya menjadi kepentingan bersama Pemerintah dan masyarakat pada sebuah bangsa. Hal ini bukan berarti Pemerintah mengintervensi segala bentuk eksistensi pendidikan tinggi yang melekat dengan prinsip otonomi perguruan tinggi dan otonomi keilmuan sebagaimana diamanatkan Undang-Undang pendidikan tinggi yang terus mengalami pergeseran paradigma sejak awal kemerdekaan bangsa Indonesia hingga zaman reformasi dan juga saat ini. Dalam tulisannya, sebagai pelaku yang ikut terlibat merumuskan beberapa Undang-Undang pendidikan saat ini, Anwar Arifin mengemukakan bahwa realitas panjang menunjukan bahwa aspek Yuridis, aspek filosofis dan sosiologis selalu diperhatikan dan dipahami dengan baik agar rumusan regulasi menjadi relefan. Namun aspek yuridis tidak mudah untuk tetap dijadikan sebagai landasan penting bagi semua rumusan undang-undang, termasuk undang-undang yang terkait dengan kepentingan pendidikan pada semua jenis dan jenjang. ${ }^{31}$

Selanjutnya Arifin menegaskan bahwa pasal 31:3 dan 5 pembukaan Undang-Undang Dasar 1945 sesungguhnya merupakan rujukan landasan Yuridis yang penting sebagai regulasi

${ }^{30}$ Tim Penyusun, Kamus Besar Bahasa Indonesia, 4th ed. (Jakarta: Penerbit PT Gramedia Pustaka Utama, 2008), 1067.

${ }^{31}$ Anwar Arifin, Politik Pendidikan Tinggi Indonesia, 1st ed. (Jakarta: Pustaka Indonesia Bersama Asosiasi Profesor Indonesia, 2013), 24. 
turunannya bagi Pemerintah agar mengupayakan pendidikan yang terbagun melalui sebuah sistem yang relevan dengan kepentingan bangsa. Dimana dalam rumusannya dikemukakan bahwa konstitusi tentang pendidikan dengan mewajibkan agar pemerintah mengusahakan dan menyelenggarakan satu sistem pendidikan nasional yang meningkatkan keimanan dan ketakwaan kepada TME serta ahklak mulia dalam rangka mencerdaskan kehidupan bangsa yang diatur Undang-Undang (Pasal 31:3). Selain itu UUD 1945 juga mengamanhkan pada pasal 31 ayat (5) agar Pemerintah memajukan ilmu pengetahuan dan teknologi dengan menjunjung tinggi nilai-nilai agama, persatuan bangsa, untuk kemajuan peradaban dan kesejahteraan umat manusia.

Kesan penting yang dikemukakan Arifin yaitu menegaskan kembali akan posisi pasal 31 ayat (3) dan ayar (5) dalam UUD 1945 yang dapat dipandang sebagai landasan yuridis yang tepat dan penting bagi Undang-Undang pendidikan tinggi yang mana menegaskan pentingnya keterlibatan Pemerintah dalam menetapkan sebuah sistem yang tentunya mempertimbangkan berbagai aspek agar pelaksanaan pendidikan itu bermuara pada tujuan dan harapan sesuai citacita bangsa yakni memajukan sumber daya msnusia yang berahklak, berilmu dan juga memiliki keimanan kepada Tuhan yang Maha Esa serta dapat memajukan ilmu pengetahuan dan teknologi.

Dengan merujuk pada beberapa sitiran penting yang dilakukan oleh Arifin, yang kemudian mengacu pada UUD 1945 pasal 31, maka hal penting yang dapat penulis pahami sebagai latar belakang setiap rumusan Undang-Undang pendidikan, khususnya pendidikan tinggi perlu memikirkan kepentingan bangsa yang bersifat universal dan komprehensif. Hal ini tentunya menjadi penting agar pendidikan tidak dijadikan sebagai sebuah kegiatan yang tidak memiliki tujuan yang spesifik namun sisi holistiksitas pun perlu dipahami dengan baik. Hal lain lagi yang perlu dipikirkan sebagai respons terhadap rumusan yang menjadi acuan aspek yuridis adalah kepentingan pendidikan yang perlu memberikan treatmen penting oleh Pemerintah untuk ikut mengupayakan terlaksanannya penyelenggaraan pendidikan dengan sebuah sistem.

Penulis memahami bahwa sebuah lema penting dalam keterlibatan Pemerintah yaitu memastikan aktualisasi sebuah sistem pendidikan secara merata sesuai tujuan berbangsa. Disini tentunya terlihat juga dalam berbagai upaya yang dilakukan pemerintah seperti merumuskan Undang-Undang pendidikan, juga merumuskan format-format secara formal seperti panduan kurikulum pendidikan tinggi yang terkait dengan sisi pendidikan, penelitian dan pengabdian kepada masyarakat yang secara minimal memiliki 24 indikator, termasuk juga indikator mengenai visi dan misi, kemahasiswaan dan kerja sama sebagaimana diwajubkan juga oleh Badan Akreditasi Nasional Perguruan Tinggi (BAN-PT) saat ini, yang perlu dipahami dengan baik bagi pelaku pendidikan. Berbagai format atau panduan-panduan yang dirumuskan dan dijadikan sebagai acuan formal tentunya akan terus berproses sesuai perkembangan dan situasi yang terjadi secara nasional maupun menglobal. Dan, sampai dini kemudian dapat dipahami bahwa pelaksanaan pendidikan tinggi, yang di dalamnya terlihat andil Pemerintah tentunya bertujuan untuk menjawab kepentingan bangsa dan negara bagi kemaslahatan masyarakat pada berbagai tingkatan dan kondisi.

\section{Kelidansi Mutual Kajian Teologis dan Yuridis}

Kelidansi mutual yang dimaksud di sini adalah bahwa terdapat hubungan keterkaitan yang saling melengkapi atau mengisi dan tidak terpisahkan secara positif antara kajian teologis 
dengan kajian Yuridis. Yaitu hubungan timbal balik yang mengacu pada struktur dan teks Kejadian pasal 1:1-31, terdapat prinsip yang baik untuk disikapi dengan oleh setiap pemangku kepentingan yang bergelut dengan kompleksitas dan kepentingan realitas pendidikan pada segala bentuk, jenis dan level. Beberapa prinsip penting yang diperoleh berdasarkan tilikan dan observasi terhadap struktur teks Kejadian 1:1-31 menghasilkan kesan penting akan kepentingan Allah di dalam self-dependence-Nya bagi kemaslahatan kebutuhan manusia yang perlu mengelola segala karya penciptaan yang dilakukan-Nya melalui aspek pendidikan yang tentunya merujuk juga pada kajian yuridis. Hal penting lain yang kemudian menjadi menarik adalah ketika memahami bahwa Allah adalah Pencipta yang selalu mengawali segala karya-Nya dengan sebuah sistem yang baik. Dan tentunya sistem ini akan memberikan output atau hasil yang dapat ketahui kualitasnya dan berdampak bagi kepentingan ciptaan yang lain.

Sisi mutual yang terlihat pada kajian teologis dan yuridis tentunya penting untuk dipahami juga dengan baik. Misalnya, tentang bagaimana cara Allah, yang dalam karya penciptaannya memperlihatkan adanya sebuah sistem yang kemudian menjadi rujukan bagi keberlangsungan semua ciptaan-Nya, termasuk dalam pelaksanaan pendidikan. Dan, bahkan sampai pada bagaimana menilai (memberikan kesan mengevaluasi) untuk mengetahui sendiri tentang hasil karya-Nya yang baik atau berkualitas, maka tentunya sesuatu yang berkualitas itu tidak dapat dipisahkan dengan sebuah pola kerja yang tersistem dengan baik. Hal ini tentunya penting juga dipahami dalam kajian pada landasan Yuridis. Karena kajian yuridis sesungguhnya merupakan sebuah rujukan penting bagi Pemerintah yang mana diberikan mandat oleh masyarakat untuk bagaimana menetapkan atau merumuskan sistem dengan berbagai rujukan praktis agar dalam pelaksanaannya, sebuah lembaga pendidikan tinggi dapat mencapai apa yang menjadi tujuan bersama yakni kwalitas pendidikan yang berdampak pada kemaslahatan masyarakat bangsa dan negara.

Pada tahap pelaksanaan, pengelola pendidikan tinggi teologi Kristen tetap menjadikan kajian Yuridis sebagai acuan formal pelaksanaan pendidikan karena diperlukannya sisi pembinaan atau pengawasan oleh pemerintah sebagai fungsi control kepada pengelola pendidikan agar pendidikan yang dikelola oleh masyarakat tidak merugikan masyarakat atau pemerintah dan gereja sebagai pengguna. Dan pada sisi konten atau isinya, dimana di dalamnya terdapat unsur-unsur seperti kurikulum yang mencakup isi dan kandungan mata kuliah dan hal lainnya, maka di sinilah kajian teologis dibutuhkan dan diberikan porsi yang proporsional agar pelaksanaan pendidikan, khususnya pendidikan tinggi teologi Kristen tidak terjebak pada konsep pendidikan sekuler secara berlebihan yang tentunya berdampak pada lulusan sesuai dengan learning outcome dari pendidikan tinggi teologi Kristen yang merujuk juga pada rumpun keilmuannya di tengah segala kondisi dan perubahan serta perkembangan ilmu pengetahuan dan teknologi.

\section{KESIMPULAN}

Kesan antithesis dalam memahami sistem pendidikan tentunya tidak akan pernah berakhir. Hal ini disebabkan karena titik tolak dan falsafah yang dipengaruhi oleh prasuposisi tertentu dalam memahami landasan pendidikan yang merujuk pada dua pengelompokan yakni kajian teologis dan filosofis yang "terkesan bersifat antithesis" tentunya tidak akan pernah berakhir. Pada sisi lain, ada kelompok yang menganggap bahwa sebuah sistem dan pelaksanaan pendidikan sebaiknya cukup dilandasi dengan kajian yuridis yang kemudian menjadi acuan dalam berbagai 
regulasi. Pada sisi lainnya lagi, ada komunitas lain yang menekankan bahwa diperlukan kajian teologis sebagai acuan formal dalam aktualisasi berbagai sistem dan hal lainnya dalam pelaksanaan pendidikan teologi Kristen. Kesan kegelisahan kemudian terjadi pada pengelola perguruan tinggi teologi dan agama Kristen yang berbasis keagamaan. Maka dengan menggunakan metode analisis narasi pada struktur teks Kejadian 1:1-31 dengan teknik pengumpulan data secara library research dan observasi leksikal, penulis hendak mendeskripsikan beberapa hal sebagai upaya aktualisasi mengenai kajian terhadap landasan teologis sebagai acuan otoritatif absolud yang juga formal sebagaimana mestinya agar dapat memperkaya pemahaman mengenai sistem pendidikan dalam perspektif analisa teks Kejadian 1:1-31 dengan beberapa simpulan penting lainnya yaitu:

Pertama. Diperlukan pemahaman yang baik mengenai upaya memosisikan kajian teologis pada tempatnya. Karena pendidikan keagamaan, khususnya pendidikan tinggi teologi dan agama Kristen yang juga terdapat jenis akademik dan vokasi tentunya memiliki kekhasannya sendiri yang perlu dipahami dalam learning outcomenya sesuai rumpun keilmuannya. Dan, semestinya kajian teologis memang perlu dipertahankan dalam keberlangsungan pendidikan teologi dan agama Kristen secara proporsional serta menekankan bahwa Allah Pencipta adalah Allah yang memiliki sebuah sistem baku yang kemudian dapat berimplikasi bagi segala hal yang dilakukan oleh ciptaannya, termasuk manusia sehingga tidak perlu dipertentangkan dengan landasan atau kajian yuridis yang berimplikasi pada realisasi pendidikan yang tersistem dan efektif.

Kedua. Kajian teologis dan Yuridis sama-sama merujuk pada suatu kepentingan yang baik yaitu terwujutnya insan masyarakat yang berahklak, berbudaya, berkualitas dan dalam segala aspek kehidupan manusia. Kajian teologis bukan menjadi pelengkap bagi keberlangsungan pelaksanaan pendidikan teologi dan keagamaan Kristen. Fakta tentang marjinalisasi kisah penciptaan dalam berbagai literatur Kristen ketika diperhadapkan dengan kisah penebusan perlu dipikirkan kembali oleh para pelaku pendidikan Kristen dan tetap memahami bahwa kisah penciptaan pun sejajar (diberikan porsi yang sama) dengan kisah penebusan. Sebab, kisah penciptaan adalah awal dari segala sesuatu yang menentukan realitas lain yang berada pada alam semesta ini. Sebabnya maka landasan pendidikan sudah ada sejak awal penciptaan, di mana Allah sendiri telah menetapkan prinsip-prinsipnya.

Ketiga. Penting untuk dipahami bahwa upaya meralisasikan segala hal dalam pendidikan, diperlukan akan pengakuan kepada Allah Tritunggal sebagai oknum utama yang mampu mewujudnyatakan segala hal. Dan, pendidikan merupakan sebuah bentuk proklamasi manusia yang satu kepada manusia lainnya mengenai segala realitas yang perlu disikapi secara baik. Karena melalui pendidikanlah, sebuah kebenaran mengenai setiap realitas dapat diketahui dan dipergunakan sebagaimana mestinya. Dan, bahwa Allah, di dalam merealisasikan segala rencananya, selalu memperlihatkan segala tatanan dengan baik. Diawali dengan tindakan "berfirman" untuk mencipta sesuatu, kemudian narator memberi gambaran mengenai realisasi penciptaan dengan kata "jadilah". Kata ini menandaskan kesan penting mengenai keseriusan Allah dalam merealisasikan segala sesuatu. Maka tentunya, upaya merealisasikan sesuatu diperlukan tingkat keseriusan dalam "kesempatan" yang di dalamnya kemudian akan terjadi dengan serius.

Keempat. Allah dalam peristiwa penciptaan sesungguhnya bukan hanya asal mencipta saja, melaikan dengan sebuah tahapan kerja yang jelas dan terukur. Maka disinilah yang 
kemudian dipahami sebagai sebuah sistem. Karena dengan sebuah "sistem" yang baik, seseorang dapat melakukan segala sesuatu berdasarkan titik berangkatnya hingga menuju pada tujuan yang diharapkan sebagaimana frasa "dan Allah melihat semuanya itu baik" atau "maka Allah melihat segala yang dijadikan-Nya itu sesungguh amat baik" adalah sebagai bentuk penilaian atau evaluasi mendalam mengenai sebuah hasil karya "mencipta." Karena, melalui proses evaluasi mendalam yang diadakan dengan bertanggungjawab dan terukur guna menilai kualitas atau mutu sesuai dengan tujuan dari pendidikan itu sendiri. Dan pada akhirnya proses penilaian atau evaluasi itu menghasilkan hasil yang baik atau bagus.

Kelima. Tedapat prinsip tentang "bingkai waktu": "jadilah petang..." jadilah pagi... adalah bagian sentral dari hal mengenai sistem pendidikan yang perlu ditata. Yang dapat merujuk pada sebuah pola atau model yang mempertimbangkan semua realitas dan kultur sebuah bangsa yakni bangsa Indonesia agar menjadi semakin berkembang dalam segala persaingan sumber daya manusia secara menglobal.

Keenam. Kajian teologis dan yuridis secara bersamaan memiliki hubungan timbal balik (mutual) yang bersifat positif. Hal ini menjadi sumbangsih positif bagi pelaku pendidikan teologi dan agama Kristen agar tidak merasa 'alergi' dengan kajian filosofis karena pada dasarnya kajian filosofis dibutuhkan sebagai rambu-rambu yang baik tentang bagaimana mengelola sebuah lembaga pendidikan. Dan, kajian teologis dibutuhkan untuk memberikan warna kekhasan pada lembaga sesuai dengan rumpun keilmuannya.

\section{REFERENSI}

Achenbach, Reinhard. Kamus Ibrani-Indonesia Perjanjian Lama. Jakarta: Yayasan Komunikasi Bina Kasih, 2008.

Arifin, Anwar. Politik Pendidikan Tinggi Indonesia. 1st ed. Jakarta: Pustaka Indonesia Bersama Asosiasi Profesor Indonesia, 2013.

Blair, Thom. The Hebrew-English Interlinear ESV Old Testament, Biblia Hebraica Stuttgartensia English Standard Version. Edited by Thom Blair. 13th ed. Wheaton, Illinois: CROSSWAY : Wheaton, Illinois - www.Esvbible.org, 2014.

Edlin, Richard J. Hakikat Pendidikan Kristen. 1st ed. Jakarta: BPK Gunung Mulia Bekerja Sama Dengan Badan Pendidikan Kristen Penabur, 2015.

Groome, Thomas H. Christian Religious Education; Pendidikan Agama Kristen. 6th ed. Jakarta: BPK Gunung Mulia, 2017.

Jatmiko, Mariani Harmadi \& Abednego Agung. "Pembelajaran Efektif Pendidikan Agama Kristen Generasi Milenial." PASCA: Jurnal Teologi dan Pendidikan Agama Kristen Vol. 16, N (2020): 64-76.

Karman, Yonky. Bunga Rampai Teologi Perjanjian Lama. Edited by BPK Gunung Mulia. 8th ed. Jakarta: BPK Gunung Mulia, 2019.

Kelley, Page H. Biblical Hebrew: An Introductory Grammar. Second edi. Grand Rapids, Michigan: William B. Eerdmans Publishing Company, 2018.

Kemahasiswaan, Direktorat Jenderal Pembelajaran dan. Buku Panduan Penyusunan Kurikulum Pendidikan Tinggi Edisi III. Edisi ke-I. Jakarta: Direktorat Jenderal Pembelajaran dan Kemahasiswaan Kementerian Riset Teknologi dan Pendidikan Tinggi, 2018. 
Koehler-Baumgartner. A Concise Hebrew Aramic Lexicon of the Old Testament. Edited by William L. Holladay. 1st ed. Leiden, the Nedherlands, 1971.

Mardiharto. "Pembangunan Sumber Daya Manusia Melalui Bidang Pendidikan Agama Kristen.” PASCA: Jurnal Teologi dan Pendidikan Agama Kristen Vol. 15, N (2019): 2832.

Neolaka, Amos. Isu-Isu Kritis Pendidikan; Utama Dan Tetap Penting Namun Terabaikan. 1st ed. Jakarta: PRENADAMEDIA GROUP, 2019.

Osborne, Grant R. The Hermeneutical Spiral: A Comprehensive Introduction to Biblical Interpretation, Tjr. Spiral Hermeneutika: Pengantar Komprehensif Bagi Penafsiran Alkitab. 1st ed. Surabaya: Momentum, 2012.

Pazmino, Robert W. Fondational Issues in Christian Education; an Introduction in Evangelical Perspective. 1st ed. Michigan: Baker Academic; a division of Baker Publishing Group Grand Rapids, Michigan, 2008.

Penyusun, Tim. Kamus Besar Bahasa Indonesia. 4th ed. Jakarta: Penerbit PT Gramedia Pustaka Utama, 2008.

Sairin, Weinata. Himpunan Peraturan Di Bidang Pendidikan. I. Bandung: PENERBIT YRAMA WIDYA, 2013.

—. Himpunan Peraturan Pendidikan Tinggi. 1st ed. Bandung: PENERBIT YRAMA WIDYA, 2015.

Sidjabad, B.S. Mengajar Secara Profesional: Mewujudkan Visi Guru Profesional. 4th ed. Bandung: Yayasan Kalam Hidup, 2011.

Suharsaputra, Uhar. Manajemen Pendidikan Perguruan Tinggi. 1st ed. Bandung: PT Rafika Aditama, 2015.

Til, Louis Berkhof \& Cornelius van. Foundations of Christian Education. Trj. Dasar Pendidikan Kristen. Kelima. Surabaya: Momentum, 2013.

Tung, Khoe Yao. Terpanggil Menjadi Pendidik Kristen Yang Berhati Gembala. 1st ed. Yogyakarta: Penerbit ANDI (Penerbit Buku dan Majalah), 2016.

Victor P, Hamilton. The New Internastional Commentary on the Old Testament: The Book of Genesis Chapter 1-7. Edited by JR R.K. Harrison \& Robert L. Hubbard. 13th ed. Grand Rapids, Michigan, 1990.

Viviano, Pauline A. Tafsir Alkitab Perjanjian Lama. Edited by Diane Bergent dan Robert J. Karris. 13th ed. Yogyakarta, 2002.

“WTT Leningrat Hebrew Old Testament Dalam BibleWorks9, LLC,” 2011. 